\title{
Spectrum of various skin nodule mimicking cutaneous adnexal tumour
}

\author{
Samanta M. ${ }^{1}$, Saini SK. ${ }^{2 *}$, Mathur D. ${ }^{3}$, Mangal N. ${ }^{4}$, Vyas K. ${ }^{5}$, Dubey A. ${ }^{6}$ \\ DOI: https://doi.org/10.17511/jopm.2020.i01.06
}

\footnotetext{
1 Matariswa Samanta, Assistant Professor, Department of Pathology, Pacific Institute of Medical Sciences, Udaipur, Rajasthan, India.

2* Seemant Kumar Saini, Assistant Professor, Department of Pathology, Pacific Institute of Medical Sciences, Udaipur, Rajasthan, India.

3 D.R. Mathur, Professor, Department of Pathology, Pacific Institute of Medical Sciences, Udaipur, Rajasthan, India.

4 Nitesh Mangal, Assistant Professor, Department of Community Medicine, Pacific Institute of Medical Sciences, Udaipur, Rajasthan, India.

5 Komi Vyas, Assistant Professor, Department of Pathology, Pacific Institute of Medical Sciences, Udaipur, Rajasthan, India.

${ }^{6}$ Anshita Dubey, Tutor, Department of Pathology, Pacific Institute of Medical Sciences, Udaipur, Rajasthan, India.
}

Introduction: Cutaneous adnexal tumors are the group of uncommon tumour usually misdiagnosed clinically with various soft tissue tumour. Therefore, histopathology is the gold standard to diagnose their histogenesis. The aim of the present study is to find out the occurrence of skin adnexal tumors according to age, sex and site distribution along with histopathological diagnosis. Materials and Methods: This retrospective study was conducted in Department of Pathology of Pacific Institute of Medical sciences, Udaipur from September 2016 to August 2019. The formalin fixed paraffin embedded tissue section was stained with hematoxylin and eosin stain for microscopical analysis. Results: A total number of 41 adnexal tumors out of which 22 males and 19 females were studied out of which 36 cases were diagnosed as benign and 5 cases were reported as malignant. The most common cutaneous adnexal tumors diagnosed as sweat gland origin followed by hair follicle, sebaceous gland and pagets disease of nipple. Majority of the cutaneous adnexal tumors reported in head and neck site in a fourth to sixth decades of life. Conclusion: Architectural features help us to diagnose different types of cutaneous adnexal tumors.

Keywords: Cutaneous adnexal tumours, Sweat gland, Histopathology

\section{Corresponding Author}

Seemant Kumar Saini, Assistant Professor, Department of Pathology, Pacific Institute of Medical Sciences, Udaipur, Rajasthan, India.

Email: seemanth.saini@gmail.com
How to Cite this Article

To Browse

Samanta M, Saini SK, Mathur DR, Mangal N, Vyas K, Dubey A. Spectrum of various skin nodule mimicking cutaneous adnexal tumour. Trop J Pathol Microbiol. 2020;6(3):35-42.

Available From

https://pathology.medresearch.in/index.php/jopm/ar ticle/view/379

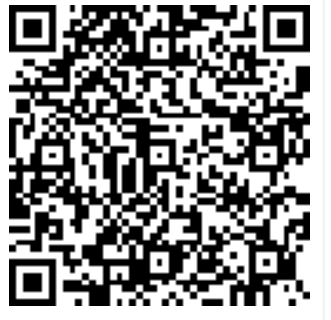

Manuscript Received 20-12-2019

Conflict of Interest No

Review Round 1
$30-12-2019$
Funding
Nil

Review Round 2
05-01-2020
Ethical Approval
Yes

Review Round 3

Accepted 09-01-2020

(C) 2020 by Matariswa Samanta, Seemant Kumar Saini, D.R. Mathur, Nitesh Mangal, Komi Vyas, Anshita Dubey and Published by Siddharth Health Research and Social Welfare Society. This is an Open Access article licensed under a Creative Commons Attribution 4.0 International License https://creativecommons.org/licenses/by/4.0/ unported [CC BY 4.0] 


\section{Introduction}

Skin adnexal tumors (SATs) are the tumors arising from the appendages of the skin such as sweat glands, sebaceous glands and hair follicles. They are often difficult to diagnose clinically and histopathologically [1]. The diagnosis of skin adnexal tumors is sometimes complicated by their ability to produce cysts or because pigmented variants have been reported. Clinically, most skin adnexal tumors have similar gross presentation hence histopathology plays an important role in reaching the correct diagnosis [2]. Color, lobulation and variable induration can be clues in narrowing down the clinical diagnosis. Dermoscopy does not reveal pathognomonic features and Immunohistochemistry has limited value in diagnosis of adnexal tumors. IHC can be used in differentiating adnexal carcinoma from metastatic carcinoma as SATs show $\mathrm{p} 63$ and CK5/6 positivity. Because of these considerations, it is common to experience uncertainty in deciding whether a particular tumor is benign or malignant; in such casesit is appropriate to give a descriptive diagnosis such as 'atypical skin adnexal tumors' or 'skin adnexal tumor of uncertain malignant potential' along with a recommendation for complete excision and consideration of follow up. However, histopathology still remains the gold standard for the diagnosis of SATs as the clinical presentation is quite indistinctive since most of the tumors present as asymptomatic papules or nodules. Cytochemical stains such as PAS, mucicarmine, alcian blue, and reticulin may aid in establishing the diagnosis. PAS stain highlights the characteristic eosinophilic globules in a spiradenoma as well as the basement membrane material surrounding the nests of tumor cells and small round droplets in a case of cylindroma. Alcian blue stain helps in demonstrating the intense staining of the stroma in a case of chondroid syringoma.

Exact categorization of benign adnexal tumor are significant because it can give a clue to the association of internal malignancy like multiple trichilemmoma and breast carcinoma which is known as cowden's syndrome [3]. Except in syndromic setting and a few additional sporadic entities with identified genetic mutations, not much is known about etiopathogenesis of adnexal tumors. UV radiation exposure and immunosuppression have been proposed as possible triggering factors.

The clinical presentation of these tumors is non-
Specific and there is high degree of overlapping of common features in different SATs. Thus, the diagnosis is principally anticipated by histopathological examination [4]. Malignant skin adnexal tumors are rare, locally aggressive and have the potential for nodal involvement and distant metastasis with a poor clinical outcome. The malignant skin adnexal tumors are vitally important to intervene as some can become metastatic resulting in morbidity and mortality [5]. Therefore, establishing the diagnosis of malignancy in skin tumors is important for therapeutic and prognostic purposes. The aim of the present study is to find out the occurrence of skin adnexal tumors according to age, sex and site distribution along with histopathological diagnosis.

\section{Materials and Methods}

Setting: The Department of Pathology, Pacific Institute of Medical Sciences, Udaipur, India.

Study design: Hospital based retrospective study.

Period of data collection: September 2016 to August 2019.

Sample size: 41 cases of skin tumors

Sampling methods and sample collection: The specimen was received in the Department of Pathology and gross findings like size, shape, colour and consistency were recorded. In all 41 cases of skin tumors were selected for the study. The patient's clinical diagnosis and the histopathological features were noted.

The material included punch biopsies and open excision specimens of various skin tumours. The specimens were fixed in $10 \%$ formalin for 24 hrs and then four $\mathrm{mm}$ thick sections were cut from representative areas and submitted for routine processing. Section were studied by light microscopy after Haematoxylin and Eosin staining. The classification for the present study was based on the WHO classification of skin tumours [6].

Inclusion and exclusion criteria: Histopathological diagnosis was mandatory for inclusion in the study. Cases clinically diagnosed as appendageal tumors, but not proven histologically to be adnexal tumors, were excluded from the study. The Keratinocytic and Melanocytic tumours of skin were excluded from the study as per the guidelines of WHO classification of appendageal tumours. 
Statistical Methods: The data were entered into MS Excel sheet and analysis was done using available options under MS Excel. Percentages were calculated.

\section{Results}

A total of 41 patients (22 males and 19 females) with adnexal tumour were included in the study. The male persons were more affected than females (Male to Female ratio was $1.15: 1$ ). Out of 41 cases, $36(87.80 \%)$ were benign while only $5(12.20 \%)$ were malignant.

Table 1 shows that the sweat gland tumors accounted for 22 (53.65\%) cases, sebaceous gland tumors $6(14.63 \%)$ cases and hair follicle tumors $14(24.40 \%)$ cases according to direction of differentiation

Table-1: Distribution of adnexal tumour according to histologic variation.

\begin{tabular}{|l|l|l|}
\hline \multicolumn{1}{|c|}{ Line of differentiation } & \multicolumn{1}{|c|}{$\begin{array}{c}\text { Number of cases } \\
(\mathrm{n}=\mathbf{4 1})\end{array}$} & $\begin{array}{c}\text { Percentage } \\
(\%)\end{array}$ \\
\hline $\begin{array}{l}\text { Sweat gland tumour(eccrine } \\
\text { origin) }\end{array}$ & 10 & 24.40 \\
\hline $\begin{array}{l}\text { Sweat gland tumour (apocrine } \\
\text { origin) }\end{array}$ & 12 & 29.26 \\
\hline Hair follicle tumour & 10 & 24.40 \\
\hline Sebaceous gland tumour & 6 & 14.63 \\
\hline Pagets disease of Nipple & 3 & 7.31 \\
\hline
\end{tabular}

Table 2 shows that among the malignant tumours, sebaceous adenoma constitutes 5 cases and only one case of malignant proliferating tricholemmal tumour.

Table-2: Distribution of adnexal tumour according to sex.

\begin{tabular}{|l|l|l|l|}
\hline \multicolumn{1}{|c|}{ Type of tumour } & Male & Female & \multicolumn{1}{|c|}{$\begin{array}{c}\text { Male female } \\
\text { ratio }\end{array}$} \\
\hline Trichoepithelima & 1 & 1 & $1: 1$ \\
\hline Pilomatricoma & 4 & 2 & $2: 1$ \\
\hline Proliferating tricholemmal cyst & 1 & 0 & $1: 0$ \\
\hline $\begin{array}{l}\text { Malignant Proliferating tricholemmal } \\
\text { tumour }\end{array}$ & 1 & 0 & $1: 0$ \\
\hline Sebaceous adenoma & & & \\
\hline Sebaceous carcinoma & 3 & 2 & $1.5: 1$ \\
\hline Eccrine poroma & 1 & 0 & $1: 0$ \\
\hline Nodular hidradenoma & 3 & 1 & $3: 1$ \\
\hline Syringocystadenoma papilliferum & 2 & 4 & $0.5: 1$ \\
\hline Hidradenoma papilliferum & 2 & 2 & $1: 1$ \\
\hline cylindroma & 1 & 3 & $0.33: 1$ \\
\hline Pagets disease of nipple & 3 & 1 & $3: 1$ \\
\hline
\end{tabular}

Table 3 revealed that majority of the adnexal tumour was more common in the head and neck followed by lower extremities and the upper extremity. Tumors were observed in all age groups ranging from 25 to 65 years.

Table-3: Distribution of adnexal tumour according to site and age.

\begin{tabular}{|c|c|c|c|}
\hline Tumour & $\begin{array}{c}\text { Number of } \\
\text { cases }\end{array}$ & Site & $\begin{array}{l}\text { Age (in } \\
\text { years) }\end{array}$ \\
\hline Trichoepithelima & 2 & $\begin{array}{l}\text { Head and } \\
\text { neck }\end{array}$ & $40-50$ \\
\hline \multirow[t]{2}{*}{ Pilomatricoma } & 3 & $\begin{array}{l}\text { Head and } \\
\text { neck }\end{array}$ & \multirow[t]{2}{*}{$45-55$} \\
\hline & 3 & $\begin{array}{l}\text { Lower } \\
\text { Extremities }\end{array}$ & \\
\hline Proliferating tricholemmal cyst & 1 & Scalp & 43 \\
\hline $\begin{array}{l}\text { Malignant Proliferating } \\
\text { tricholemmal tumour }\end{array}$ & 1 & $\begin{array}{l}\text { Head and } \\
\text { neck }\end{array}$ & 53 \\
\hline \multirow[t]{2}{*}{ Sebaceous adenoma } & 3 & Face & \multirow[t]{2}{*}{$30-40$} \\
\hline & 2 & Scalp & \\
\hline Sebaceous carcinoma & 1 & Scalp & $55-60$ \\
\hline Eccrine poroma & 4 & $\begin{array}{l}\text { Lower } \\
\text { Extremities }\end{array}$ & $40-60$ \\
\hline \multirow[t]{3}{*}{ Nodular hidradenoma } & 2 & \begin{tabular}{|l} 
Lower \\
Extremities
\end{tabular} & \multirow[t]{3}{*}{$35-50$} \\
\hline & 3 & $\begin{array}{l}\text { Upper } \\
\text { Extremities }\end{array}$ & \\
\hline & 1 & Face & \\
\hline \multirow[t]{3}{*}{ Syringocystadenoma papilliferum } & 2 & $\begin{array}{l}\text { Lower } \\
\text { Extremities }\end{array}$ & \multirow[t]{3}{*}{$25-45$} \\
\hline & 1 & Trunk & \\
\hline & 1 & $\begin{array}{l}\text { Head and } \\
\text { neck }\end{array}$ & \\
\hline \multirow[t]{3}{*}{ Hidradenoma papilliferum } & 1 & $\begin{array}{l}\text { Lower } \\
\text { Extremities }\end{array}$ & \multirow[t]{3}{*}{$25-40$} \\
\hline & 2 & $\begin{array}{l}\text { Upper } \\
\text { Extremities }\end{array}$ & \\
\hline & 1 & Face & \\
\hline Cylindroma & 4 & Scalp & $50-65$ \\
\hline Pagets disease of nipple & 3 & Breast & $50-60$ \\
\hline
\end{tabular}

\section{Discussion}

The possibility of adnexal tumours should be considered when there is an epithelial proliferation in the dermis and that also it looks different from keratinocytic tumors like squamous cell carcinoma, basal cell carcinoma or amelanocytic melanoma. Therefore before going straight to immunohistochemistry (IHC) a algorithmic approach based on haematoxylin and eosin section followed by histological differentiation of various adnexal 
Proliferation likes sebaceous gland, sweat gland or hair follicle mass be considered [7]. The incidence of benign tumour was more as compared to malignant SAT.

In the present study 36 out of 41 cases were benign $(87.80 \%)$ and only 5 cases $(12.20 \%)$ were found to be malignant. There were similar report found in the Prasad BVS et al which reported $93.75 \%$ benign and $6.25 \%$ malignant cases[4]. Similar findings were observed by other studies conducted by Kaur $\mathrm{K}$ et al, Valand AG et al ,Sharma A et al study and Radhika $\mathrm{K}$ respectively [2,8-9].

The present study showedthat majority of the adnexal tumours was present in the age group of 40-60 years and male being more than female as 22 were male out of total 41 cases. Similar findings were observed in the studies done by Rajalakshmi $\mathrm{V}$ et al and Kaur $\mathrm{K}$ et al $[8,11$,$] . While in contrast Arora$ $A$ et al study showed that the most common age group affected by the tumour was between 20- 40 years and predominantly occurred in females compared to males [12].

The ratio of male to female ratio was more as the ratio was $1.15: 1$ in the present study. The study done by Nair PS et al showed that the male to female ratio was $1: 2.3$ and the study by Pantola $C$ et al found ratio of $1.8: 1 \quad[13,14]$. The most common anatomical site found to be head and neck region (53\%) which was 22 out of 41 cases. Similar findings were observed by other studies conducted by Prasad BVS et al , Arora A et al, Gandhi R et al and Kaur $K$ et al study $[4,12,3,8]$.

Majority of adnexal tumour was present as fleshy colour, multiple papules or solitary nodules $[15,16]$. Tumour arising from sweat gland were found to be very dominant. Out of 41 cases, 22 cases (53\%) of sweat gland tumours were diagnosed in the present study. Similar finding were observed in the study conducted by Pantola $C$ et al, Pujani $M$ et al and Prasad BVS et al study respectively $[4,14,17]$. Another study conducted by Suri Jet al showed pilomatricoma (hair follicle tumour)to be the most common one [18]. The Pilomatricoma tumour in the present study showed dermal proliferations of irregular tumour island and intervening stroma. It comprised of two type of cells that is basaloid cells and shadow (ghost) cells. The basaloid cells were seen in the periphery of the tumour and centre of the island was occupied by shadow cells, having eosinophilic cytoplasm, distinct cell border and no nuclear staining (Figure 1 ).
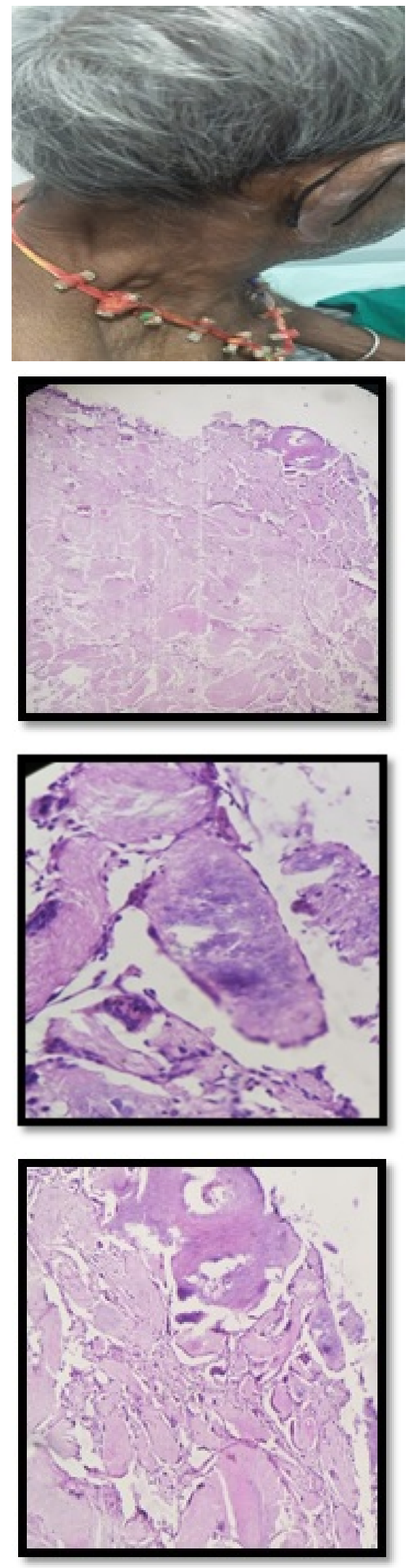

Fig- 1: A: 70-year female presented with PostAuricular swelling (Pilomatricoma), B: 10x Showsbasaloid cells and shadow cells proliferation, C:40x Shows Ghost Cells in Pilomatricoma, D: Shows Ghost Cells with Focal Areas of Calcification. 
The present study showed nodular hidraadenoma to be the commonest sweat gland origin tumour Figure-1 showed that 40-year-old female having frontal swelling at the base of nose with solitary nodule which was $0.5-2 \mathrm{~cm}$, firm in consistency, slightly mobile since last 4 months. It was diagnosed as nodular hidradenoma by microscopy. Microscopic picture revealed well circumscribed dermal nodule showing island of basaloid cells, round to oval nucleus and basophilic cytoplasm with few clear cells, having clear or eosinophilic cytoplasm. Cells were arranged in solid area with duct like structure and scanty cystic changes (Figure 2).
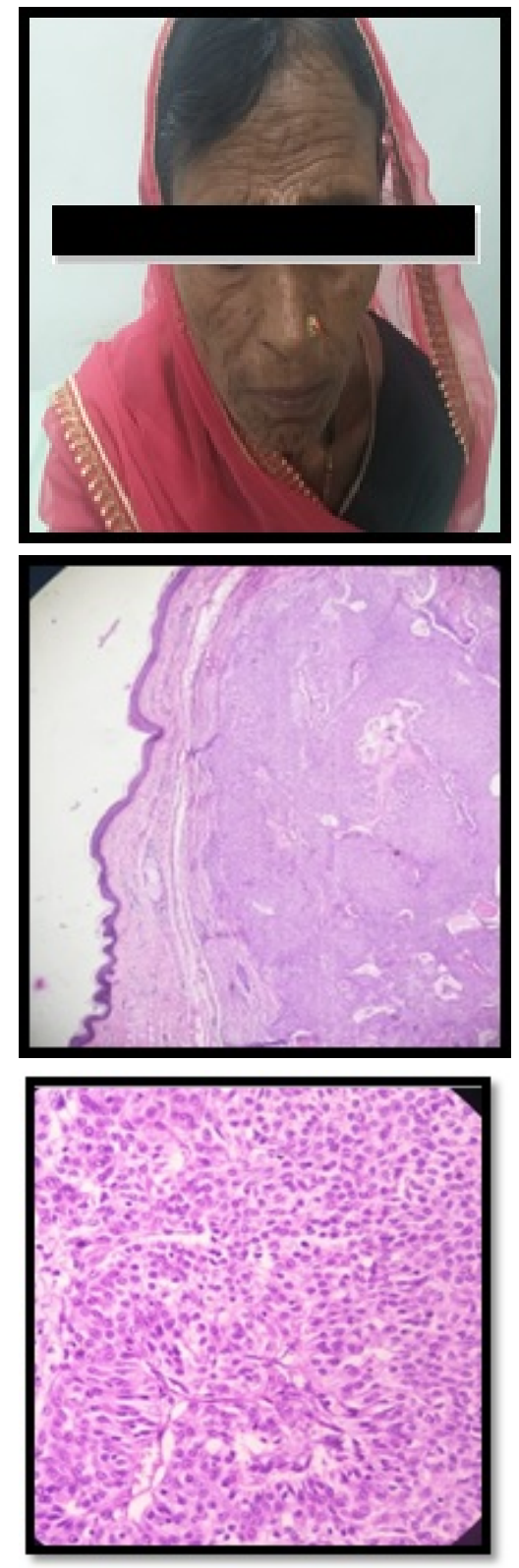

Fig-2: A: 40-year female presented with frontal swelling of base of Nose. B: 10x shows nodular hidradenoma. C: 40x shows nodular hidradenoma constituted of basaloid cells and clear type of cells.
Four cases of hydradenoma papillforum were reported in the age group of 25- 40 years at the upper and lower extremities.

The microscopic picture showed multiple dermal papillae, papillae comprises of two layer of cells forming duct like epithelium, basaloid cells and columnar cells.

Stroma of the papillae comprised of connective tissue and blood vessels (Figure 3). Three cases of hydradenoma papillforum were found in females patients in the study conducted by Radhika $\mathrm{K}$ et al [10].
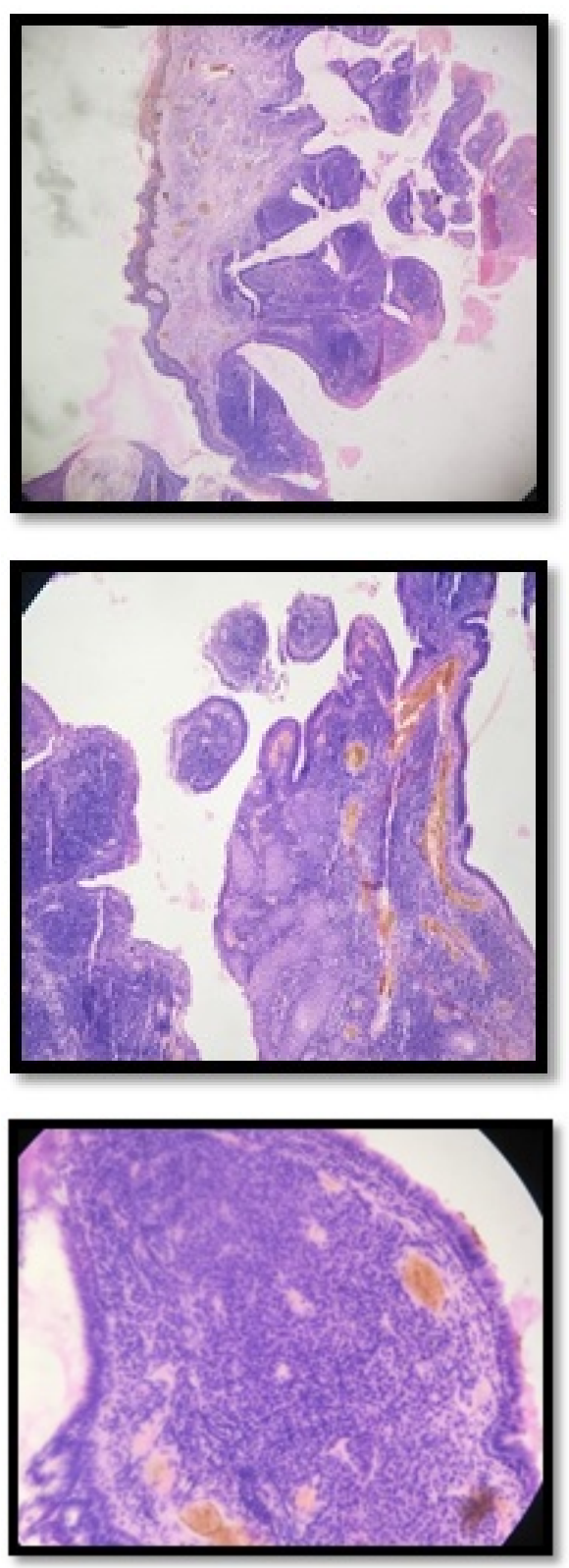

Fig-3: A: 10x Shows Hydradinoma Papiliformis, B: 10x Shows Multiple Papillae, C: 40x Shows Double layered papillae having Columnar and basal epithelium. 
Two cases of Trichoepithelioma found in head and neck. Microscopically revealedwell circumscribed comprising of island of basaloid cells with hair follicle differentiation in a cellular stroma small focus of calcifications. But no retraction artifact identified in the stroma(Figure 4). Whereas two cases of Trichoepithelioma were reported in Sharma A et al study and three cases of Trichoepithelioma were reported by Suri J et al and Sahu A et al study $[1,9,18]$.
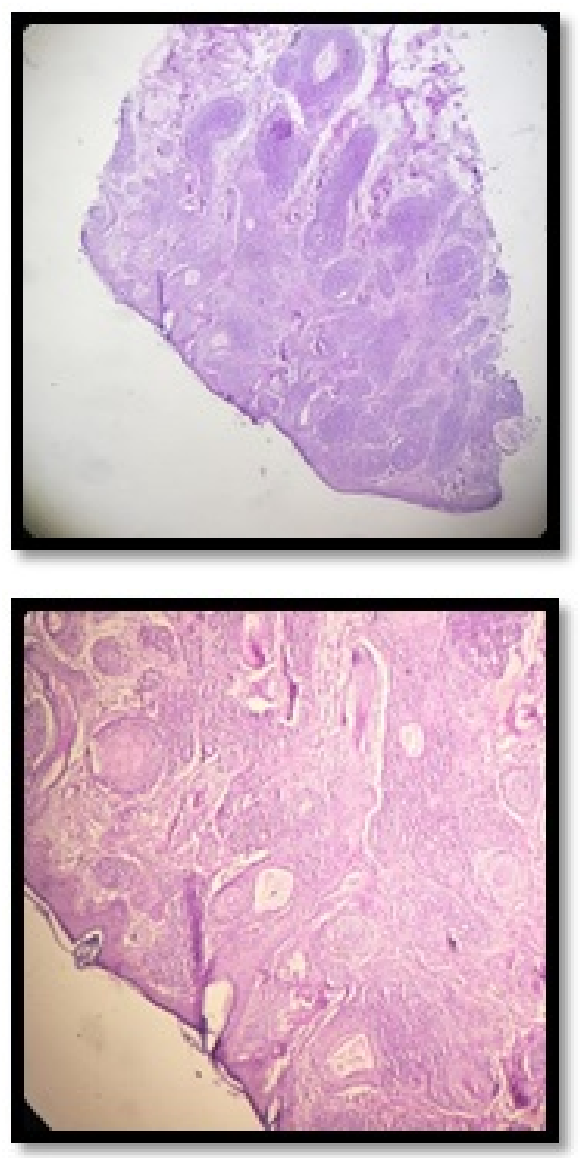

Fig 4: A: $10 x$ Shows Trichoepithelioma. B: 40x Shows Multiple clusters of basaloid cells arising from basal layer of epidermis and proliferating towards dermis layers.

A total number of five malignant adnexal tumour was found, out of which one case of malignant proliferating tricholemmal tumour was found in head and neck region in a 43 years male patient and one case of sebaceous carcionoma also diagnosed as scalp nodule in a 57 years male patient and three cases of mammary pagets disease were diagnosed as malignant adnexal tumour in the age group of 50-60 years.

Pagets disease of nipple revealed breast tissue with nipple areola region and basal layer of epidermis showing pigments and clusters of vacuolated cells.
This vaculolated cells had high $\mathrm{N}: \mathrm{C}$ ratio, nuclear pleomorphism and bizarre hyperchromatic nucleus (Figure 5).
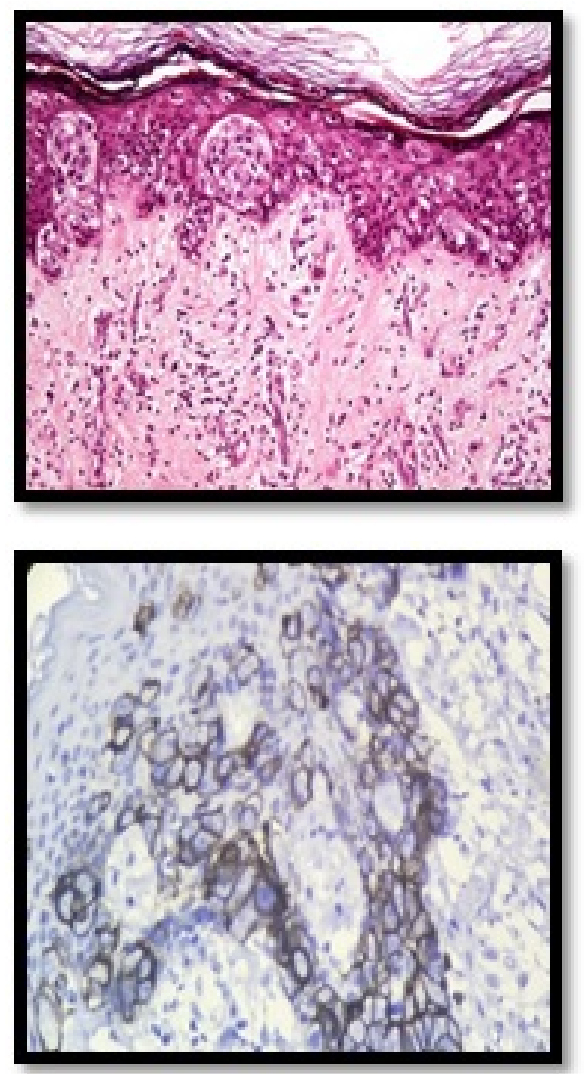

Fig-5: A: 40x Paget Disease of Skin (Breast Swelling), B: (40x) Er Positivity Reveals Paget Disease
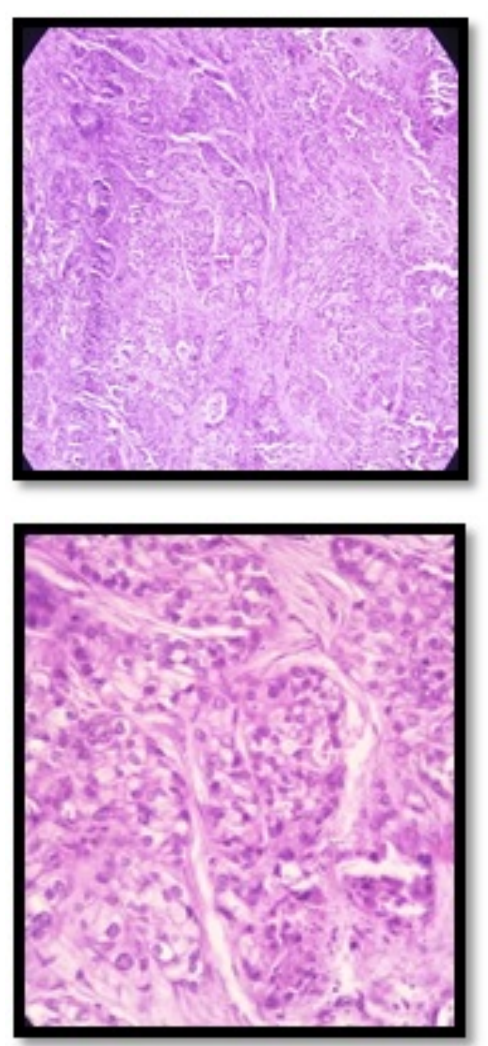
Fig 6: A: 10x Shows Sebaceous Carcinoma. B: 40x Shows Malignant Sebaceous glands

The study done by Kaur $\mathrm{K}$ et al found sebaceous carcinoma was common malignant adnexal tumour $(19.64 \%)$ and the common age group was more than 60 years of age [8]. The Sebaceous Carcinoma characterized by tumour cells which showed irregular epithelial lobules with an infiltrating growth pattern in the dermis.

These tumour cells comprised island of sebaceosus gland with high N: C, nucleoplemorphism, atypical mitotis and vaculolated cytoplasm (Figure 6).

As per the recent guidelines and classification of WHO skin tumour and the pagets disease of nipple have been included in the study

Limitation of the present study: IHC has been done according to the availability in the institute.

\section{Conclusion}

The present study of skin adnexal tumour indicated that majority of such type of tumour are benign in nature and only few cases of malignancy has been observed. The predilection of such tumor is predominantly head and neck region followed by extremities and chest and the common age group was between 4th-6th decades and have predilection for males.

Skin adnexal tumour was always challenging because of its nonspecific and overlapping clinical features, few of them specially the malignant one can easily mimic clinically and grossly with various soft tissue sarcoma like MFH (Malignant fibrous histiocytoma) or sarcoma with rhabdoid differentiation.

Therefore, histopathology is a gold standard to diagnose dermal adnexal tumor. The single centre study could help us to know the characteristics of adnexal tumour in hospital based population of southern region of Rajasthan.

\section{What this study adds to the existing knowledge?}

Five rare cases of malignant adnexal tumour were observed out of which pagets disease of nipple and sebaceous carcinoma were rare identities. Immunohistochemistry marker was used in the cases of pagets disease of nipple.

\section{Author's contributions}

Dr. Matariswa Samanta: Concepts, Design, Literature search, Data acquisition, Manuscript preparation, Manuscript editing, work as the Principle author

Dr. Seemant Kumar Saini: Manuscript editing, Manuscript review work as the Corresponding author

Dr. D R Mathur: Diagnosis, Data acquisition, Manuscript preparation, Manuscript editing

Dr. Nitesh Mangal: Data analysis

Dr. Komi Vyas: Data collection

Dr. Anshita Dubey: Data collection

\section{Reference}

01. Sahu A, Dilip KS, Nayak SK, Agrawal KC. Skin Adnexal Tumors- A Histopathological Study of 60 Cases at a Tertiary Care Centre. Ann Pathol Lab Med. 2018;5(3)215-220.

doi:[Article:https://doi.org/10.21276/APALM.1787]

[Crossref]

02. Valand AG, Ansari SAH, Sinha RK, Jadhav VC. A clinicopathological study of adnexal tumors of skin in a tertiary care research hospital. Int J Health Sci Res. 2016; 6(12)52-58.

[Crossref]

03. Gandhi R, Srinivasan S. A Morphologic Study of Cutaneous Adnexal Tumours. Nat J Lab Med. 2016;5(4)8-11.

doi:

[Article:https://doi.org/10.7860/NJLM/2016/21800:2 161][Crossref]

04. Prasad BVS, Faheem MK, Anuradha B, Lakshmi AV, Sreenivasulu M, Prasad DN. Histopathological Evaluation and Review of Cutaneous Adnexal Tumors (Cats) - A Research Study. IOSR J Dent Med Sci. 2018;17(2)7-11.

doi: [Article:https://doi.org/10.9790/08531702030711][Crossref]

05. Le Boit PE, Burg G, Weedon D, Sarasin A. World Health Organization Classification of Tumours Pathology and Genetics of Skin Tumours. 3rd Edition, France- IARC Press, International Agency for Research on Cancer. 150 cours Albert Thomas, F-69008 Lyon, France; 2006. [Crossref] 
06. Santa Cruz DJ. Tumors of the skin, In- Fletcher CD, editor, Diagnostic Histopathology of Tumors. 3rd ed, Philadelphia- Churchill Living Stone Elsevier. 2007, Vol(2)1423-1526.

[Crossref:https://search.crossref.org/?typename $=$ Journal+Article\& $q=$ Tumors of the skin, InFletcher CD, editor, Diagnostic Histopathology of Tumors]

07. Pantola C, Kala S, Agarwal A, Amit S, Pantola S. Cutaneous adnexal tumours- A clinicopathological descriptive study of 70 cases. World J Pathol. 2013;2;77-82.

[Crossref:https://search.crossref.org/?type-

name $=$ Journal+Article $\& q=$ Cutaneous adnexal tumours- A clinicopathological descriptive study of 70 cases]

08. Fulton EH, Kaley JR, Gardner JM. Skin Adnexal Tumors in Plain Language A Practical Approach for the General Surgical Pathologist. Arch Pathol Lab Med. 2019;143(7)832-851.

doi:[Article:https://doi.org/10.5858/arpa.2018-0189RA][Crossref]

09. Kaur K, Gupta K, Hemrajani D, Yadav A, Mangal K. Histopathological analysis of skin adnexal tumors- A three-year study of 110 cases at a tertiary care center. Indian J Dermatol. 2017;62(4)400-406.

doi: [Article:https://doi.org/10.4103/ijd.IJD_380_16] [Crossref:Crossref]

10. Sharma A, Paricharak DG, Nigam JS, Rewri S, Soni PB, Omhare $A$, et al. Histopathological study of skin adnexal tumours-Institutional study in South India. J Skin Cancer. $2014 ; 4 ; 543756$.

doi:[Article:http://dx.doi.org/10.1155/2014/543756]

[Crossref]

11. Radhika K, Phaneendra BV, Rukmangadha N, Reddy MK. A study of biopsy confirmed skin adnexal tumours- experience at a tertiary care teaching hospital. J Clin Sci Res. $2013 ; 2(3) ; 132-138$.

[Crossref]

12. Suri J, Mahajan D, Koul KK, Kumari R. A Clinicopathological Analysis of Skin Adnexal Tumours- Four Year Retrospective Study. JK Sci. 2016;18(4)248-251.

[Crossref:https://search.crossref.org/?typename $=$ Journal+Article $\& q=A \quad$ Clinicopathological Analysis of Skin Adnexal Tumours- Four Year Retrospective Study]
13. Kaur R, Kumar V, Mehra K, Gupta N, Singh A. Histopathological evaluation of Skin Tumours. Indian J Pathol Oncol. 2016;3(4);627-631.

doi: [Article:https://doi.org/10.5958/23946792.2016.00116.2][Crossref]

14. Rajalakshmi V, Selvakumar S, Rajeswari K, Meenakshisundaram K, Veena G, Ramachandran P. Case series of skin adnexal tumours. J Clin Diagn Res. 2014;8(9)7-10.

doi:

[Article:https://doi.org/10.7860/JCDR/2014/8710.48 44][Crossref]

15. Arora A, Nanda A, Lamba S. Cytohistopathological correlation of skin adnexal tumors- A short series. J Cytol. 2018;35(4)204207.

doi:

[Article:https://dx.doi.org/10.4103\%2FJOC.JOC_63_ 17][Crossref]

16. Nair PS. A clinicopathologic study of skin appendageal tumors. Indian J Dermatol Venereol Leprol. 2008;74(5)550.

doi: [Article:https://doi.org/10.4103/03786323.44339][Crossref]

17. Pujani M, Madaan GB, Jairajpuri ZS, Jetley $S$, Hassan MJ, Khan S. Adnexal tumors of skin- An experience at a tertiary care center at Delhi. Ann Med Health Sci Res. 2016;6(5)280-285.

doi:

[Article:https://dx.doi.org/10.4103\%2Famhsr.amhsr_ 339_14][Crossref:Crossref]

18. Klein Wiccan E, Seykora Jt. Tumours of the epidermal appendages, In- Elder DE, Elenitsas R, Johnson BL Jr Murphy GF (eds), Lever's Histopathology of the skin. Lippincott, Williams \& Wilkins, Philadelphia. 2005; p 867-914. [Crossref] 